\title{
Expression and prognostic relevance of endothelin-B receptor in vulvar cancer
}

\author{
ELKE ELTZE $^{1}$, MATTEO BERTOLIN ${ }^{3}$, EBERHARD KORSCHING $^{1}$, \\ PIA WÜLFING ${ }^{2}$, TIZIANO MAGGINO ${ }^{4}$ and RALPH LELLÉ ${ }^{2}$ \\ ${ }^{1}$ Institute of Pathology, ${ }^{2}$ Department of Obstetrics and Gynecology, University of Münster, \\ D-48149 Münster, Germany; Departments of ${ }^{3}$ Oncology and Surgical Sciences, and \\ ${ }^{4}$ Obstetrics and Gynecology, University of Padova, Padova, Italy
}

Received December 4, 2006; Accepted January 8, 2007

\begin{abstract}
Overexpression of endothelin (ET)-1 and its receptors, $\mathrm{ET}_{\mathrm{A}} \mathrm{R}$ and $\mathrm{ET}_{\mathrm{B}} \mathrm{R}$, commonly referred to as the 'ET-axis', has been demonstrated to play a role in cancer progression for various human tumours. Based on these results we propose a similar role of the expression of the ET-axis in vulvar cancer. Expression of the ET-axis was investigated immunohistochemically using tissue microarrays with tumour samples of 68 vulvar cancer patients. Samples were obtained from patients undergoing local excision or radical vulvectomy. ET-1 expression of tumour cells correlated highly significantly with early stages of vulvar cancer $(\mathrm{p}=0.004)$, whereas neither $\mathrm{ET}_{\mathrm{A}} \mathrm{R}$ nor $\mathrm{ET}_{\mathrm{B}} \mathrm{R}$ expression showed any association with TNM stages. High staining levels of $\mathrm{ET}_{\mathrm{B}} \mathrm{R}$ in the tumour tissue were significantly related to tumour progression $(\mathrm{p}=0.01)$ and early metastases $(\mathrm{p}=0.09)$; low $\mathrm{ET}_{\mathrm{B}} \mathrm{R}$ staining intensity correlated with longer relapse-free survival $(\mathrm{p}=0.019)$. In patients with $\mathrm{ET}_{\mathrm{B}} \mathrm{R}$ overexpressing low-stage tumours (pT1-2) we observed a significantly reduced overall survival and disease-free survival ( $\mathrm{p}=0.036$ and 0.021 , respectively). $\mathrm{ET}_{\mathrm{A}} \mathrm{R}$ expression and $\mathrm{ET}_{\mathrm{B}} \mathrm{R}$ expression were significantly correlative $(\mathrm{p}=0.018)$. Accordingly, co-expression of both receptors was related to tumour progression $(\mathrm{p}=0.022)$ and an increased risk for local recurrence $(\mathrm{p}=0.005)$. These results suggest that, in addition to established histological and clinical prognostic factors, analysis of ET-receptor and, in particular, of $\mathrm{ET}_{\mathrm{B}} \mathrm{R}$ expression by means of simple immunohistochemical analysis might improve prediction of the prognosis for patients with vulvar squamous cell carcinoma.
\end{abstract}

Correspondence to: Dr Elke Eltze, Institute of Pathology, University of Münster, Domagkstrasse 17, D-48149 Münster, Germany

E-mail: eltze@uni-muenster.de

Key words: endothelins, $\mathrm{ET}_{\mathrm{B}} \mathrm{R}$, endothelin receptors, immunohistochemistry, vulvar squamous cell carcinoma

\section{Introduction}

Malignant vulvar tumours represent $5 \%$ of all gynaecologic malignancies (1). Ninety percent of vulvar tumours are squamous cell carcinomas. In general, two groups of vulvar cancers can be distinguished depending on patients' age and the presence of human papilloma virus. Most patients $(>65 \%)$ are older than 65 years $(2,3)$. However, tumours in the other group with younger patients seem to be associated with human papilloma virus (HPV), especially HPV16. Moreover, tumours in the younger group are frequently of basaloid tumour type $(4,5)$. Within the last years a global trend has become apparent according to which an increasing number of younger patients are developing vulvar cancer, which has been attributed to HPV $(4,6)$. Treatment of vulvar cancer is usually surgical with radical vulvectomy and bilateral groin and pelvic lymphadenectomy, where applicable in combination with adjuvant radiotherapy (7). The five-year overall survival rate is $68 \%$. Survival worsens with an increase in tumour stage, age and nodal stage $(8,9)$ all of which have been established as poor prognostic factors. In addition, molecular markers are needed to enable a better discrimination of more aggressive tumour phenotypes and to potentially facilitate a targeted molecular therapy in the future.

The endothelins and their receptors, referred to as the ET-axis, play an emerging role in cancer development. Endothelin-1 (ET-1) is a vasoconstrictor that was initially isolated from endothelial cells (10). As a potent mitogen, ET-1 has direct influence on cell proliferation and a strong synergy with many growth factors that have been implicated in the progression of various tumour entities (11-14). ET-1 exerts its effects via its receptors, $\mathrm{ET}_{\mathrm{A}} \mathrm{R}$ and $\mathrm{ET}_{\mathrm{B}} \mathrm{R}$ (15). With respect to $\mathrm{ET}_{\mathrm{B}} \mathrm{R}$ expression in human malignancies contradictory data have been reported. Whereas $\mathrm{ET}_{\mathrm{B}} \mathrm{R}$ seems to function as a possible survival factor in oligodendrogliomas (16), decreased $\mathrm{ET}_{\mathrm{B}} \mathrm{R}$ expression was associated with poorer clinical outcome (17-19) in other cancer entities (e.g., malignant melanoma or prostate cancer).

To the best of our knowledge this is the first study that analyses expression of the ET-axis in primary vulvar cancer and correlates the results with clinicopathological and follow-up data. 
Table I. Correlation of ET-1, $\mathrm{ET}_{\mathrm{A}} \mathrm{R}$ and $\mathrm{ET}_{\mathrm{B}} \mathrm{R}$ expression with clinicopathological characteristics in patients with vulvar cancer.

\begin{tabular}{|c|c|c|c|c|c|}
\hline Parameter & Patients & $(\%)$ & ET-1 (\%) & $\mathrm{ET}_{\mathrm{A}}$-receptor $(\%)$ & $\mathrm{ET}_{\mathrm{B}}$-receptor $(\%)$ \\
\hline & 68 & 100 & $8 / 68(12)$ & $10 / 68(17)$ & $30 / 68(44)$ \\
\hline Tumour stage & & & $*$ & & \\
\hline pT1a & 4 & 6 & $2 / 4 \quad(50)$ & $0 / 4$ & $1 / 4 \quad(25)$ \\
\hline pT1b & 18 & 26 & $4 / 18(22)$ & 2/18 (11) & $7 / 18 \quad(39)$ \\
\hline pT2 & 32 & 47 & $2 / 32 \quad(6)$ & 6/32 (19) & $17 / 32(53)$ \\
\hline pT3 & 12 & 18 & $0 / 12 \quad(0)$ & 2/12 (17) & $5 / 12 \quad(42)$ \\
\hline pT4 & 2 & 3 & $0 / 2 \quad(0)$ & $0 / 2 \quad(0)$ & $0 / 2 \quad(0)$ \\
\hline \multicolumn{6}{|l|}{ Nodal stage } \\
\hline pNO & 39 & 57 & 6/39 (15) & 4/39 (10) & $17 / 39(44)$ \\
\hline $\mathrm{pN} 1$ & 17 & 25 & 2/17 (12) & 3/17 (18) & $8 / 17 \quad(47)$ \\
\hline $\mathrm{pN} 2$ & 12 & 18 & $0 / 12 \quad(0)$ & $3 / 12 \quad(25)$ & $5 / 12 \quad(42)$ \\
\hline cM stage & & & $*$ & & \\
\hline M0 & 59 & 87 & 8/59 (14) & 9/59 (15) & 28/59 (47) \\
\hline M1 & 9 & 13 & $0 / 9 \quad(0)$ & $1 / 9 \quad(11)$ & $2 / 9 \quad(22)$ \\
\hline \multicolumn{6}{|c|}{ Histological grading } \\
\hline G1 & 8 & 12 & $2 / 8 \quad(25)$ & $1 / 8 \quad(13)$ & $5 / 8 \quad(63)$ \\
\hline $\mathrm{G} 2$ & 44 & 65 & $5 / 44(11)$ & $5 / 44(11)$ & $17 / 44(39)$ \\
\hline G3 & 16 & 23 & $1 / 16 \quad(6)$ & $4 / 16(25)$ & $8 / 16 \quad(50)$ \\
\hline \multicolumn{6}{|l|}{$\begin{array}{l}\text { Proliferation index } \\
(\mathrm{Ki} \mathrm{67)}(\%)\end{array}$} \\
\hline$<10$ & 17 & 25 & $3 / 18(18)$ & 4/17 (24) & $9 / 17 \quad(53)$ \\
\hline $11-40$ & 33 & 49 & $3 / 33 \quad(9)$ & $5 / 33$ & $14 / 33(42)$ \\
\hline$>40$ & 18 & 26 & 2/18 (11) & $1 / 18 \quad(6)$ & $7 / 18 \quad(39)$ \\
\hline Basaloid type & 19 & 28 & 2/19 (11) & $1 / 19 \quad(5)$ & $6 / 19 \quad(32)$ \\
\hline Keratinizing type & 49 & 72 & $6 / 49(12)$ & 9/49 (18) & $24 / 49(49)$ \\
\hline HPV & 31 & 46 & $3 / 31 \quad 10)$ & 4/31 (13) & $13 / 31(42)$ \\
\hline \multicolumn{6}{|l|}{ Age } \\
\hline$<50$ & 17 & 25 & $1 / 17 \quad(6)$ & $2 / 17$ & $9 / 17 \quad(53)$ \\
\hline$>50$ & 51 & 75 & $7 / 51(14)$ & $8 / 51 \quad(16)$ & $21 / 51(41)$ \\
\hline
\end{tabular}

*Significant correlation.

\section{Materials and methods}

Patients and tumour specimens. Sixty-eight patients who between 1988 and 2004 had been diagnosed with primary vulvar cancer at the Department of Obstetrics and Gynaecology, University of Münster, Germany, were included in the study. The patients' mean age was $62 \pm 16$ years (range, $26-93$ years). Treatment consisted of radical or partially radical vulvectomy. Thirty-three patients $(55 \%)$ received adjuvant radiation therapy, two of them in combination with chemotherapy according to the scheme for radiochemotherapy of cervical carcinomas (20). Follow-up was performed quarterly until October 2004. Formalin-fixed and paraffin-embedded tumour-tissue blocks for all patients were obtained from the files of the Institute of Pathology (University of Münster). The presence of invasive squamous cell carcinoma was confirmed for each block selected. To ensure standardised tumour classification all slides were reviewed and reclassified according to the TNM classification [UICC, 6th edition (21)].

Tissue microarray (TMA). For construction of the tissue microarray (TMA), representative paraffin-embedded tumour tissue samples served as donor blocks. Sections were cut from each donor block and stained with haematoxylin and eosin. For each of the 68 tumour samples two morphologically characteristic areas were chosen from both the tumour invasion line and the tumour centre. These areas were circled on the H\&E slides. From each of these circled regions a cylindrical 
Table II. Correlation of ET-1, $\mathrm{ET}_{\mathrm{A}} \mathrm{R}$ and $\mathrm{ET}_{\mathrm{B}} \mathrm{R}$ expression with prognostic factors in patients with vulvar cancer.

\begin{tabular}{lccccc}
\hline Parameter & Patients & $(\%)$ & ET-1 $(\%)$ & ET $_{\mathrm{A}}$-receptor $(\%)$ & ET $_{\mathrm{B}}$-receptor (\%) \\
\hline & 68 & 100 & $8 / 68(12)$ & $10 / 68(17)$ & $30 / 68(44)$ \\
Alive (recurrence-free) & 20 & 29 & $3 / 20(15)$ & $2 / 20(10)$ & $6 / 20(30)$ \\
Death of disease & 19 & 28 & $1 / 19(5)$ & $3 / 19(16)$ & $12 / 19(63)$ \\
Tumour-unrelated death & 6 & 9 & $1 / 6(17)$ & $1 / 6(17)$ & $3 / 6 \quad(50)$ \\
3-year survival & $28 / 43$ & 65 & $5 / 28(18)$ & $5 / 28(18)$ & $14 / 28(50)$ \\
5-year survival & $21 / 38$ & 55 & $3 / 21(14)$ & $3 / 21(14)$ & $10 / 21(48)$ \\
Tumour progression & & & & & $*$ \\
Local recurrence & 22 & 32 & $4 / 22(18)$ & $2 / 22(9)$ & $11 / 22(50)$ \\
Distant metastasis & 23 & 34 & $1 / 23(4)$ & $4 / 23(17)$ & $13 / 23(57)$ \\
\hline
\end{tabular}

*Significant correlation.

0.6-mm core biopsy was acquired and precisely arrayed into a new recipient paraffin block using a manual tissue arrayer (Beecher Instruments, Silver Spring, MD, USA). The final tissue set consisted of one block containing 276 tumour sample cores. The presence of squamous cell carcinoma in the arrayed samples was verified on H\&E sections of the TMA.

Immunohistochemistry. Four- $\mu \mathrm{m}$ sections were cut from the TMA block and mounted on poly-L-lysine-coated glass slides. After pre-treatment with a steamer (Multi-Gourmet-Steamer, Braun, type 3216) for antigen retrieval (30 min), sections were stained immunohistochemically for Ki-67 using an automated immunostainer (Dako-Autostainer). Mouse monoclonal antiKi-67 antibody (clone MIB-1; Dako Diagnostics, Hamburg, Germany, anti-human Ki-67 antigen, code no. M7240) was used as primary antibody in a dilution of 1:1000. The ratio of MIB-1 expressing cells (distinct nuclear staining) against the total number of cells was evaluated for each tissue cylinder (22).

Staining for $\mathrm{ET}_{\mathrm{A}} \mathrm{R}$ and $\mathrm{ET}_{\mathrm{B}} \mathrm{R}$ was also performed in a multistep semi-automatic procedure (Dako-Autostainer; Dako Diagnostics), as previously described (14). Briefly, two sheep polyclonal antibodies for $\mathrm{ET}_{\mathrm{A}} \mathrm{R}$ and $\mathrm{ET}_{\mathrm{B}} \mathrm{R}$ were used $\left(\mathrm{ET}_{\mathrm{A}^{-}}\right.$ receptor antiserum, product no. 210-507-C250; $\mathrm{ET}_{\mathrm{B}}$-receptor antiserum, product no. 210-506-C250; Affinity Bioreagents, Golden, CO, USA). For staining of ET-1, a monoclonal mouse antibody (anti-endothelin-1 MAb, clone TR.ET.48.5; Affinity Bioreagents) was used. Bladder cancer tissue known to express ET-1 and $\mathrm{ET}_{\mathrm{A}} \mathrm{R}$ and smooth muscle tissue with $\mathrm{ET}_{\mathrm{B}} \mathrm{R}$ activity were used as positive, and omission of the primary antibody was used as negative control. Semi-quantitative analysis was performed by two of the authors (E.E., M.B.), both blinded to the clinical data. The cytoplasmic immunostaining intensity of the tumour cells was categorised semi-quantitatively into 4 groups as previously described (14), namely negative (score 0 ), weak (score 1), moderate (score 2), and strong (score 3). The final score was designated as negative or positive in the following way: score $0-1$, negative; and score $2-3$, positive.
In situ hybridisation (ISH). The chromogenic ISH assays (Inform ${ }^{\circledR} \mathrm{HPV}$ ) were performed according to the manufacturer's recommendations using the BenchMark ${ }^{\mathrm{TM}}$ Automated Slide Staining System (Ventana Inform HPV Test, Tucson, AZ, USA). Patient specimens known to be positive for either oncogenic or non-oncogenic HPV were used as controls. The probe cocktails demonstrate positive hybridisation to the following 12 high-risk genotypes: $16,18,31,33,35,39,45$, $51,52,56,58$ and 66 , as well as 5 low-risk genotypes: 6,11 , 42,43 and 44 (23).

Statistical analysis. Statistical analysis was performed by use of the statistical software package SPSS 11.0.1 ${ }^{\mathrm{TM}}$ (SPSS Inc., USA). All clinical and pathologic parameters were correlated with IHC results by means of contingency tables and $\chi^{2}$ test. For calculation of overall and disease-free survival times Kaplan-Meier estimates were generated (24). Survival curves were compared by log-rank test $(25)$. P-values $<0.05$ were considered to be statistically significant.

\section{Results}

The series of 68 patients with squamous cell carcinoma of the vulva analysed in this study was well-balanced with respect to clinicopathological parameters such as age, TNM, HPV status, grading, basaloid cancer type (basaloid versus keratinising), and proliferation index (Ki-67) (Table I). Median follow-up was 26 months (range, 2-147 months). Within that time 19 patients died from vulvar carcinoma, 6 died due to nontumour-related reasons. Fourteen patients were lost to followup. Overall survival was $65 \%$ at 3 years and $55 \%$ at 5 years, respectively.

Immunohistochemistry. The expression of ET-1, $\mathrm{ET}_{\mathrm{A}} \mathrm{R}$, and $\mathrm{ET}_{\mathrm{B}} \mathrm{R}$ presented as homogenous cytoplasmic staining (Fig. 1). The staining intensity of ET-1, $\mathrm{ET}_{\mathrm{A}} \mathrm{R}$ and $\mathrm{ET}_{\mathrm{B}} \mathrm{R}$ varied between different tumours from complete absence to strong staining. Moderate or strong staining intensity (referred to as 'ET- 


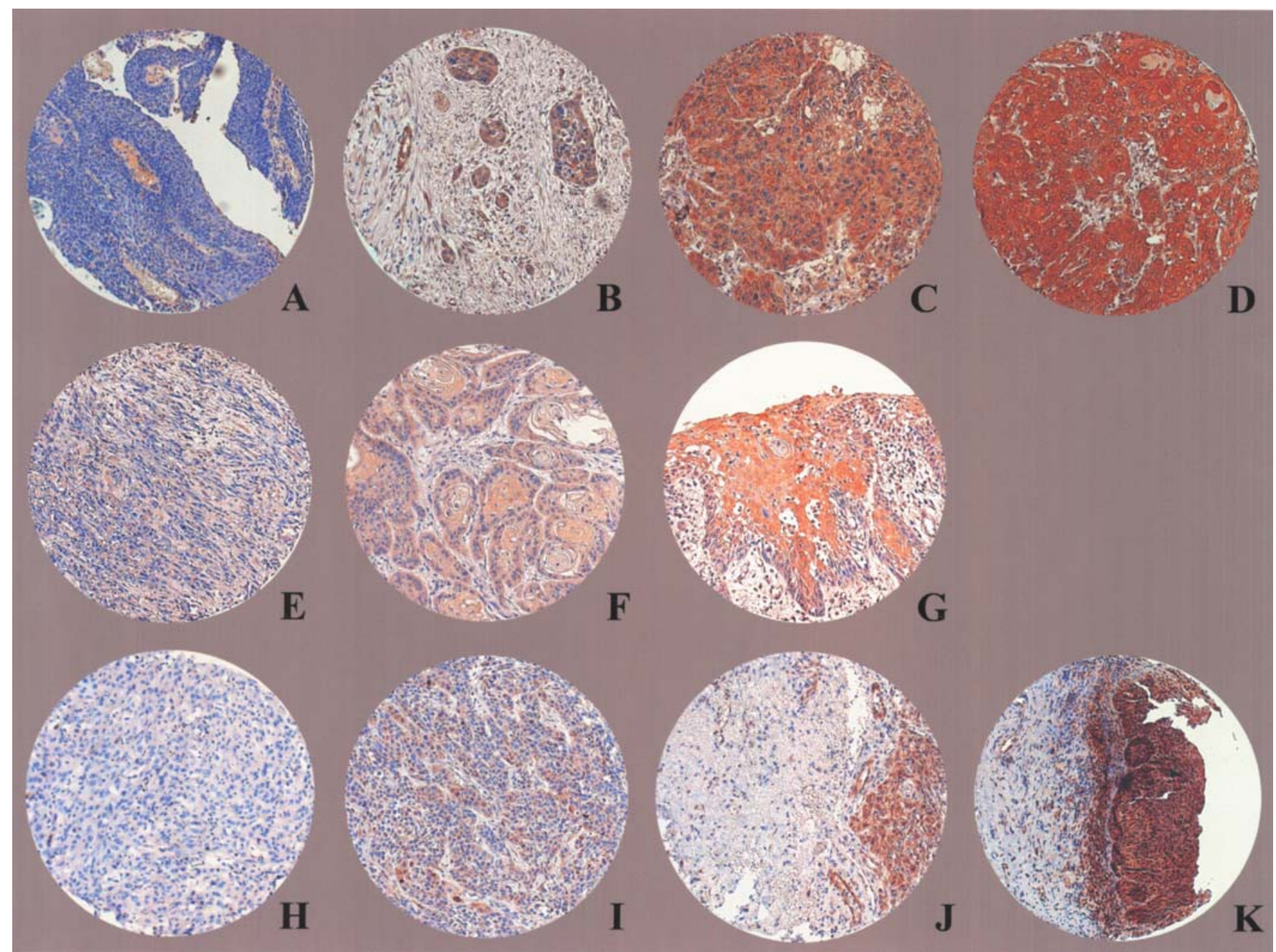

Figure 1. Immunohistochemical expression of tumours: x20 objective magnification; ET-1 (A, negative; $\mathrm{B}$, weak; C, moderate; $\mathrm{D}$, strong), ET $\mathrm{A}_{\mathrm{A}}$ (E, negative; F, weak; G, moderate), $\mathrm{ET}_{\mathrm{B}} \mathrm{R}$ (H, negative; I, weak; J moderate; K, strong).

positive') was present for ET-1 in 8 of 68 (12\%) and for $\mathrm{ET}_{\mathrm{B}} \mathrm{R}$ in 30 of $68(44 \%)$ tumours. Vulvar carcinomas (10 of 68$)$ $(17 \%)$ showed a moderate staining reaction for $\mathrm{ET}_{\mathrm{A}} \mathrm{R}$ (Table I, Fig. 1). For $E_{A} R$, no strong expression pattern was detected. We found a significant correlation between expression of $\mathrm{ET}_{\mathrm{A}} \mathrm{R}$ and $\mathrm{ET}_{\mathrm{B}} \mathrm{R}(\mathrm{p}=0.01)$. Also, expression of ET-1 was associated with that of both ET receptors $\left(\mathrm{ET}_{\mathrm{A}} \mathrm{R}, \mathrm{p}=0.009\right.$; $\mathrm{ET}_{\mathrm{B}} \mathrm{R}, \mathrm{p}=0.011$ ).

Correlation between expression of ET-axis, clinicopathological parameters and follow-up. We could not demonstrate any correlation between the expression of the ET receptors and established clinicopathological characteristics such as histological grade, tumour size, lymph node or distant metastases. In contrast ET-1 expression correlated significantly with smaller tumour size $(\mathrm{p}=0.035)$, whereas no ET-1 expression was present in pT3 and pT4 tumours. No correlation was found between ET-1 expression and presence of lymph node distant metastases or histological grade. Also, expression of the ET-axis did not significantly correlate with the HPV status, tumour type or proliferation index (Ki-67).

However, expression of $\mathrm{ET}_{\mathrm{B}} \mathrm{R}$ significantly correlated with an adverse outcome (Table II). Accordingly, $\mathrm{ET}_{\mathrm{B}} \mathrm{R}$ expression was more frequently detected in patients with progression of disease ( $\mathrm{p}=0.01$, Fig. 2), e.g. development of local recurrence or distant metastases. Consistently, patients with low $\mathrm{ET}_{\mathrm{B}} \mathrm{R}$ expression had a significantly longer relapse-free survival ( $\mathrm{p}=0.019$, Fig. 3).

Survival analysis revealed a significantly worse outcome in patients with early tumour stages (pT1+2 disease) displaying tumours overexpressing $\mathrm{ET}_{\mathrm{B}} \mathrm{R}(\mathrm{p}=0.036$, Fig. 4A) compared to those with $\mathrm{ET}_{\mathrm{B}} \mathrm{R}$-negative tumours. Time to progression (TTP) was also shorter in patients with increased $\mathrm{ET}_{\mathrm{B}} \mathrm{R}$ expression $(\mathrm{p}=0.093)$. With respect to stages $\mathrm{pT} 1-2$ $\mathrm{ET}_{\mathrm{B}} \mathrm{R}$ was indicative of a significantly worse TTP $(\mathrm{p}=0.021$, Fig. 4B).

\section{Discussion}

Endothelin-1 and its two receptors, $\mathrm{ET}_{\mathrm{A}} \mathrm{R}$ and $\mathrm{ET}_{\mathrm{B}} \mathrm{R}$, have recently been demonstrated to be overexpressed in various human tumours. It has clearly been shown that the ET-axis promotes the growth and progression of carcinomas by influencing apoptosis, angiogenesis and signalling of several growth factors (26). The emerging role of the ET-axis in cancer has led to the development of selective ET-receptor antagonists 


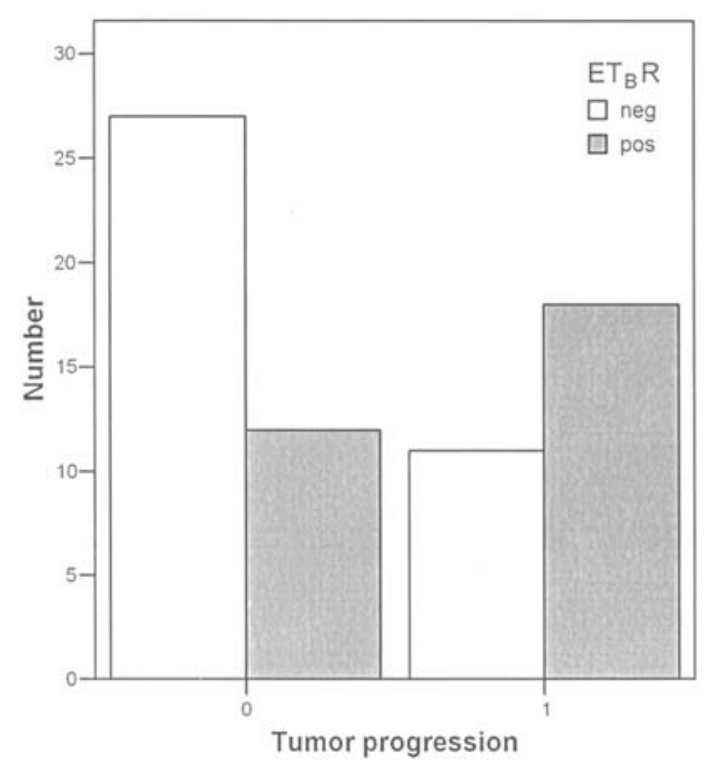

Figure 2. Significantly elevated $\mathrm{ET}_{\mathrm{B}} \mathrm{R}$ expression with vulvar cancer progression $(\mathrm{p}=0.01)$.

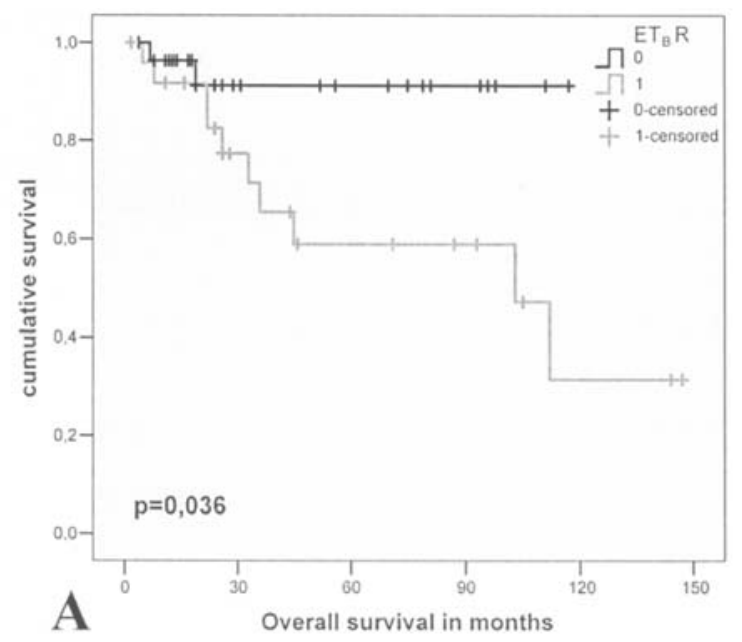

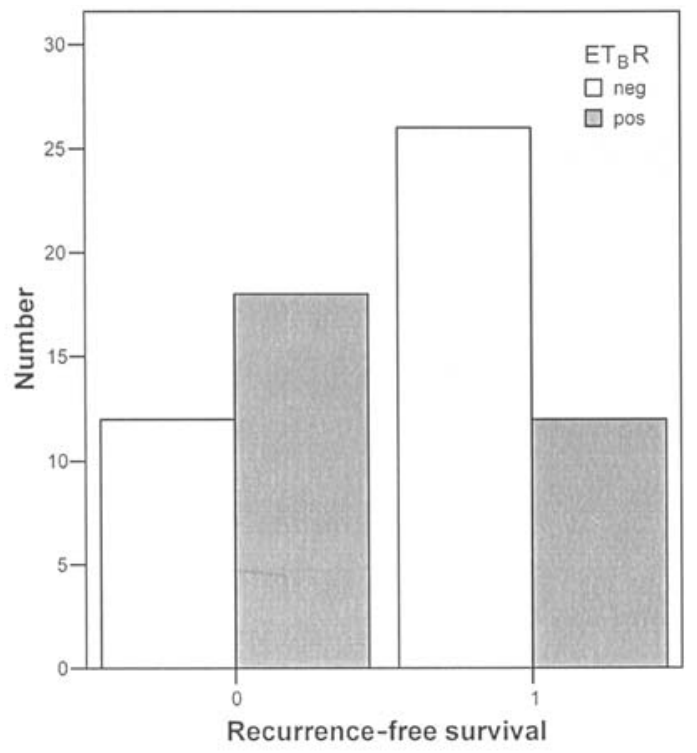

Figure 3. Significantly reduced $\mathrm{ET}_{\mathrm{B}} \mathrm{R}$ expression in relapse-free survival of vulvar cancer patients $(\mathrm{p}=0.019)$.

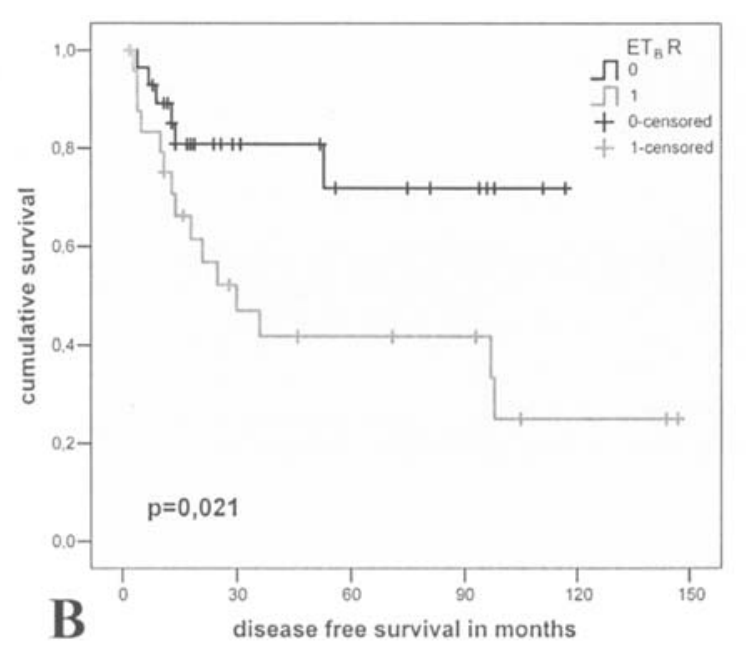

Figure 4. (A) Overall survival time of 54 patients with vulvar carcinoma $\mathrm{pT} 1-2$ in relation to $\mathrm{ET}_{\mathrm{B}} \mathrm{R}$ expression ( $\mathrm{p}=0.036$ ). (B) Disease-free survival time (DFST) of 54 patients with vulvar carcinoma $\mathrm{pT} 1-2$ in relation to $\mathrm{ET}_{\mathrm{B}} \mathrm{R}$ expression $(\mathrm{p}=0.021)$.

for molecular-targeted therapy. First clinical trials with a selective $\mathrm{ET}_{\mathrm{A}} \mathrm{R}$ antagonist showed its ability to delay disease progression in patients with hormone-refractory prostate cancer (27).

Active angiogenesis as assessed by increased microvessel density (MVD) and strong VEGF (vascular endothelial growth factor) expression has been reported to correlate with an unfavourable prognosis in vulvar cancer.

To the best of our knowledge we are the first to report on expression of ET-1, $\mathrm{ET}_{\mathrm{A}} \mathrm{R}$ and $\mathrm{ET}_{\mathrm{B}} \mathrm{R}$ in vulvar cancer. Our results indicate that the ET-axis is overexpressed in the majority of vulvar cancers. Our data are in line with recent studies on expression of the ET-axis in other tumour entities. Nelson et al were the first to show that the ET-axis in prostate cancer is overexpressed compared with the normal prostate gland (28). The same authors postulated a role for ET-1 as a mediator of osteoblastic response in metastatic prostate cancer. Subsequent experiments with a selective $\mathrm{ET}_{\mathrm{A}} \mathrm{R}$ inhibitor showed reduced bone formation in a mouse model (29). In ovarian cancer, ET-1 was demonstrated to promote tumour cell proliferation in several ovarian cancer cell lines (30), and in human ovarian tissue, expression of the ET-axis, in particular ET-1 and $\mathrm{ET}_{\mathrm{A}} \mathrm{R}$ expression, was significantly up-regulated in neoplastic tissue compared with normal ovarian tissue (11). Moreover, in breast cancer increased expression of $\mathrm{ET}_{\mathrm{A}} \mathrm{R}$ has been demonstrated to correlate with a worse prognosis and resistance to chemotherapy (31).

In our study, both ET receptors, particularly $\mathrm{ET}_{\mathrm{B}} \mathrm{R}$, were overexpressed at tissue level. Our finding of frequent $\mathrm{ET}_{\mathrm{B}} \mathrm{R}$ overexpression in vulvar cancer is consistent with our previous data of breast cancer patients. In accordance with the breast cancer data published by Alanen et al, we also found $\mathrm{ET}_{\mathrm{B}} \mathrm{R}$ 
to be expressed more frequently than $\mathrm{ET}_{\mathrm{A}} \mathrm{R}$ (53.4 vs. $46.5 \%$, respectively) $(14,32)$. In melanoma (18) and lung cancer (33) $\mathrm{ET}_{\mathrm{B}} \mathrm{R}$ also seems to be the predominantly expressed receptor, whereas in other tumour entities, e.g. prostate (19), ovarian (11) and cervical cancer (34), $\mathrm{ET}_{\mathrm{A}} \mathrm{R}$ has been reported to be overexpressed more frequently.

Prognostic relevance of $\mathrm{ET}_{\mathrm{B}} \mathrm{R}$ has been described in uveal melanoma where reduced $\mathrm{ET}_{\mathrm{B}} \mathrm{R}$ expression correlated with death from metastatic disease (17)

Our results indicate a potential role of $\mathrm{ET}_{\mathrm{B}} \mathrm{R}$ in cancer progression with overexpression in patients with disease progression and decreased expression with longer relapsefree survival. The significantly worse outcome in stage pT1 and pT2 patients with $\mathrm{ET}_{\mathrm{B}} \mathrm{R}$ overexpressing tumours suggests that analysing $\mathrm{ET}_{\mathrm{B}} \mathrm{R}$ expression in vulvar cancer at the time of diagnosis might help to identify patients with an unfavourable prognosis.

Our data also point to a potential therapeutic approach using specific $\mathrm{ET}_{\mathrm{B}} \mathrm{R}$ antagonists. To date, the selective $\mathrm{ET}_{\mathrm{B}} \mathrm{R}$ antagonist (BQ 788) has only been tested pre-clinically in vitro and in animal models. In human melanoma cells BQ 788 induced growth inhibition and cell death (35), but no effects were observed in cervical cancer cell lines (34). Also, a combined $\mathrm{ET}_{\mathrm{A}} \mathrm{R} / \mathrm{ET}_{\mathrm{B}} \mathrm{R}$ antagonist (bosentan) has been demonstrated to induce apoptosis in human glioblastoma cell lines (36). Therefore an $\mathrm{ET}_{\mathrm{B}} \mathrm{R}$ or $\mathrm{ET}_{\mathrm{A}} \mathrm{R} / \mathrm{ET}_{\mathrm{B}} \mathrm{R}$ antagonist may be helpful in vulvar carcinoma of advanced stage.

\section{Acknowledgements}

We thank Judith Obernüfemann for her excellent technical assistance, Susanne Kölsch for revising the manuscript and Holger Eltze for his accomplished execution of the tables and figures.

\section{References}

1. Wilkinson EJ: Premalignant and malignant tumours of the vulva. In: Blausteins Pathology of the Female Tract. Chapter 3. Kurman RJ (ed). New York, pp99-149, 2006.

2. Sturgeon SR, Brinton LA, Devesa SS and Kurman RJ: In situ and invasive vulvar cancer incidence trends (1973-1987). Am J Obstet Gynecol 166: 1482-1485, 1992.

3. Joura EA: Epidemiology, diagnosis and treatment of vulvar intraepithelial neoplasia. Curr Opin Obstet Gynecol 14: 39-43, 2002.

4. Quinn MJ: Epidemiology of cervical, vulvar and vaginal cancers. In: . Chapter 1. Gershenson DM, McGuire DM, Gore M, Quinn MJ and Thomas G (eds). Philadelphia, PA, pp20-30, 2004.

5. Trimble CL, Hildesheim A, Brinton LA, Shah KV and Kurman RJ: Heterogeneous etiology of squamous carcinoma of the vulva. Obstet Gynecol 87: 59-64, 1996.

6. Maclean AB: Vulval cancer: the past 100 years, and into the next century: the Presidential Oration, British Society for the Study of Vulval Disease, 2002. J Obstet Gynaecol 24: 491-497, 2004.

7. Dhar KK and Woolas RP: Changes in the management of vulval cancer. Best Pract Res Clin Obstet Gynaecol 17: 529-542, 2003.

8. Hopkins MP, Reid GC, Vettrano I and Morley GW: Squamous cell carcinoma of the vulva: prognostic factors influencing survival. Gynecol Oncol 43: 113-117, 1991.

9. Marsden DE and Hacker NF: Contemporary management of primary carcinoma of the vulva. Surg Clin North Am 81: 799-813, 2001.
10. Yanagisawa M, Kurihara H, Kimura S, Goto K and Masaki T: A novel peptide vasoconstrictor, endothelin, is produced by vascular endothelium and modulates smooth muscle $\mathrm{Ca}^{+}$ channels. J Hypertens Suppl 6: S188-S191, 1988.

11. Bagnato A, Salani D, Di CV, Wu-Wong JR, Tecce R, Nicotra MR, Venuti A and Natali PG: Expression of endothelin 1 and endothelin A receptor in ovarian carcinoma: evidence for an autocrine role in tumour growth. Cancer Res 59: 720-727, 1999.

12. Battistini B, Chailler P, D'Orleans-Juste P, Briere N and Sirois P: Growth regulatory properties of endothelins. Peptides 14: 385-399, 1993.

13. Gohji K, Kitazawa S, Tamada H, Katsuoka Y and Nakajima M: Expression of endothelin receptor a associated with prostate cancer progression. J Urol 165: 1033-1036, 2001.

14. Wulfing P, Diallo R, Kersting C, Wulfing C, Poremba C, Rody A, Greb RR, Bocker W and Kiesel L: Expression of endothelin-1, endothelin-A and endothelin-B receptor in human breast cancer and correlation with long-term follow-up. Clin Cancer Res 9: 4125-4131, 2003.

15. Rubanyi GM and Polokoff MA: Endothelins: molecular biology, biochemistry, pharmacology, physiology and pathophysiology. Pharmacol Rev 46: 325-415, 1994.

16. Anguelova E, Beuvon F, Leonard N, Chaverot N, Varlet P, Couraud PO, Daumas-Duport C and Cazaubon S: Functional endothelin ET B receptors are selectively expressed in human oligodendrogliomas. Brain Res Mol Brain Res 137: 77-88, 2005.

17. Smith SL, Damato BE, Scholes AG, Nunn J, Field JK and Heighway J: Decreased endothelin receptor B expression in large primary uveal melanomas is associated with early clinical metastasis and short survival. Br J Cancer 87: 1308-1313, 2002.

18. Demunter A, Wolf-Peeters C, Degreef H, Stas M and van den Oord JJ: Expression of the endothelin-B receptor in pigment cell lesions of the skin. Evidence for its role as tumour progression marker in malignant melanoma. Virchows Arch 438: 485-491, 2001.

19. Nelson JB, Chan-Tack K, Hedican SP, Magnuson SR, Opgenorth TJ, Bova GS and Simons JW: Endothelin-1 production and decreased endothelin $\mathrm{B}$ receptor expression in advanced prostate cancer. Cancer Res 56: 663-668, 1996.

20. Thomas GM: Improved treatment for cervical cancer - concurrent chemotherapy and radiotherapy. N Engl J Med 340: 1198-1200, 1999.

21. Sobin LH and Wittekind C: TNM Classification of Malignant Tumours. 6th edition. p272, 2002.

22. Wulfing $\mathrm{P}$, Diallo R, Muller C, Wulfing C, Poremba C, Heinecke A, Rody A, Greb RR, Bocker W and Kiesel L: Analysis of cyclooxygenase-2 expression in human breast cancer: high throughput tissue microarray analysis. J Cancer Res Clin Oncol 129: 375-382, 2003.

23. Qureshi MN, Rudelli RD, Tubbs RR, Biscotti CV and Layfield LJ: Role of HPV DNA testing in predicting cervical intraepithelial lesions: comparison of HC HPV and ISH HPV. Diagn Cytopathol 29: 149-155, 2003.

24. Kaplan EL and MP: Non-parametric estimation from incomplete observations. J Am Stat Assoc 53: 457, 1958.

25. Mantel N: Evaluation of survival data and two new rank order statistics arising in its consideration. Cancer Chemother Rep 50: $163,1936$.

26. Nelson J, Bagnato A, Battistini B and Nisen P: The endothelin axis: emerging role in cancer. Nat Rev Cancer 3: 110-116, 2003.

27. Carducci MA, Padley RJ, Breul J, Vogelzang NJ, Zonnenberg BA, Daliani DD, Schulman CC, Nabulsi AA, Humerickhouse RA, Weinberg MA, Schmitt JL and Nelson JB: Effect of endothelin-A receptor blockade with atrasentan on tumour progression in men with hormone-refractory prostate cancer: a randomized, phase II, placebo-controlled trial. J Clin Oncol 21: 679-689, 2003.

28. Nelson JB, Hedican SP, George DJ, Reddi AH, Piantadosi S, Eisenberger MA and Simons JW: Identification of endothelin-1 in the pathophysiology of metastatic adenocarcinoma of the prostate. Nat Med 1: 944-949, 1995.

29. Nelson JB, Nguyen SH, Wu-Wong JR, Opgenorth TJ, Dixon DB, Chung LW and Inoue N: New bone formation in an osteoblastic tumour model is increased by endothelin-1 over-expression and decreased by endothelin A receptor blockade. Urology 53: 1063-1069, 1999.

30. Moraitis S, Langdon SP and Miller WR: Endothelin expression and responsiveness in human ovarian carcinoma cell lines. Eur J Cancer 33: 661-668, 1997. 
31. Wulfing P, Tio J, Kersting C, Sonntag B, Buerger H, Wulfing C, Euler U, Boecker W, Tulusan AH and Kiesel L: Expression of endothelin-A-receptor predicts unfavourable response to neoadjuvant chemotherapy in locally advanced breast cancer. Br J Cancer 91: 434-440, 2004.

32. Alanen K, Deng DX and Chakrabarti S: Augmented expression of endothelin-1, endothelin-3 and the endothelin-B receptor in breast carcinoma. Histopathology 36: 161-167, 2000.

33. Ahmed SI, Thompson J, Coulson JM and Woll PJ: Studies on the expression of endothelin, its receptor subtypes, and converting enzymes in lung cancer and in human bronchial epithelium. Am J Respir Cell Mol Biol 22: 422-431, 2000.
34. Venuti A, Salani D, Manni V, Poggiali F and Bagnato A: Expression of endothelin 1 and endothelin A receptor in HPVassociated cervical carcinoma: new potential targets for anticancer therapy. FASEB J 14: 2277-2283, 2000.

35. Lahav R, Heffner G and Patterson PH: An endothelin receptor B antagonist inhibits growth and induces cell death in human melanoma cells in vitro and in vivo. Proc Natl Acad Sci USA 96: 11496-11500, 1999.

36. Harland SP, Kuc RE, Pickard JD and Davenport AP: Expression of endothelin (A) receptors in human gliomas and meningiomas, with high affinity for the selective antagonist PD156707. Neurosurgery 43: 890-898, 1998. 